\title{
EXPLORING POPULATIONS OF ORGANIZED INTERESTS IN POST-COMMUNIST CENTRAL AND EASTERN EUROPE
}

\author{
Michael Dobbins, Rafael Labanino, and \\ Brigitte Horváthová
}

\section{Introduction}

How have populations of interest organizations developed in the post-communist era? While scholars have focused on "births" and "deaths" of interest organizations in the USA and the European Union (EU) (Berkhout et al., 2015; Gray \& Lowery, 1996), we still have little knowledge on how interest group landscapes are developing in post-communist democracies. The very particular context of the abrupt collapse of command economies and authoritarian regimes followed by a fast-paced transition to democracy and market economy is likely to have fundamentally impacted interest group populations. This unprecedented trajectory of simultaneous economic, political and social transformation, often combined with nation-building, offers a unique chance to assess changes and stability in populations of organizations.

After having looked at organizational development under communism and post-transition survival rates in Chapter 2, a series of new questions arise. First, how radically were interest group populations transformed by the transition to a market economy, democracy and in some cases nation-building? To what extent did EU accession, full membership and the integration into trans-European structures reshape the organizational landscape? To what degree have organizational populations been affected by internal reform processes? And, at what point did populations of organizations become "saturated"?

We address these questions by exploring the formation and density rates of organized interests in Poland, Hungary, the Czech Republic and Slovenia - the latter two of which became independent countries and all of which joined the EU in 2004. We again focus on energy, healthcare and higher education (HE). All three policy areas have concentrated interests (e.g. energy producers, university professors, the medical profession) and more diffuse interests (environmental groups, 
students, patients) and, importantly, are currently subject to strong, but varying degrees of reform and harmonization pressures reinforced by Europeanization.

To track changes over time, we compiled databases of all nationally operating interest groups in these three policy areas based on court registries, while also checking whether the organizations existed during communism. This enables us to assess the volatility and continuity of each different interest group system from a cross-country and cross-policy perspective. In doing so, we broke down organizations into specific types (e.g. patients vs. medical profession, students vs. academic profession, energy producers vs. consumers, clean vs. dirty energy, see below) to gain a clearer picture of "birth" and density rates within individual policy areas.

First, we briefly review some existing research on organization ecology. We then discuss the specific post-communist context, while deriving numerous working hypotheses on external and internal processes, which may affect organizational populations. Against this background, we present descriptive statistics reflecting population developments, while discussing change and stability based on our theoretical framework. The conclusions summarize our findings and offer ideas for future research.

\section{Theoretical background and working hypotheses}

As outlined in Chapter 2, population ecology studies the founding, mortality and density of organizations on the aggregate level. Hannan and Freeman (1977) emphasized that the ability of organizations to adapt to environmental changes is limited. Organizations are characterized by structural inertia stemming from both internal pressures (material and human resources are not easily transferable, lack of information, status quo bias within organizations) and external pressures (legal and fiscal barriers to entry or exit, cost of information, legitimacy constraints, problem of collective rationality). They defined populations as aggregates of organizations (rather than members) that are "relatively homogenous in terms of environmental vulnerability" (1977, p. 934). The question is then not how individual organizations adapt to changes in the organizational environment, but how change impacts the "size distributions" and "the diversity of organizational forms within broadly defined areas of activity" (1977, p. 957). In other words, organizational selection happens at the level of populations and not individual organizations.

Another key theoretical concept is density dependence. It explains "the variation in founding and mortality rates as functions of organizational density" (Hannan \& Carroll, 1992, p. 15). Organizations initially struggle to legitimize their existence. With the gradual legitimation of an organizational form, the need for justification decreases (Hannan \& Freeman, 1989), thus reducing the cost of organizing. However, as density grows, the "supplies of potential organizers, members, patrons and resources become exhausted" (Hannan \& Carroll, 1992). Subsequently, the competition for resources also increases, potentially resulting in a saturation effect, which may inhibit new foundations. Thus, organizational populations are expected to evolve as an inverted "U-shaped" curve, i.e. $\cap$. 
Another well-known theory of interest group formation and stability is the political opportunity structure (POS) approach (Meyer \& Imig, 1993; Meyer \& Minkoff, 2004), which focuses on the political and economic environment. Meyer and Imig (1993, p. 255) argue that "external political circumstances set the context in which the calculus of participation takes place, determining the urgency of particular issues, and the scope and intensity of conflict". Thus, any type of system-level crisis or transformation may induce opportunities for mobilization. Yet not only political crises, but also changes in the balance of power or major policy reforms may induce new interest groups to jump into the playing field. POS theory differentiates both between structural changes and signals, and issue-specific versus general openings in the polity. Structural changes are profound changes in political alignments and policies, whereas visible signals in the political environment are rather symbolic in nature (Meyer \& Minkoff, 2004, p. 1464).

Drawing from these two schools of thought, we formulate several working hypotheses to grasp developments in four post-communist democracies. Based on density dependence theory, we first explore whether there are "saturation effects" in our populations of post-communist organizations. In other words, do we first observe a phase of gradual growth as organizations struggle to legitimize themselves and then a "flattening out" before organizational births decline as the playing field becomes crowded out?

Hypothesis 1: Interest group formation in CEE is density-dependent, characterized by gradual growth, then a plateau and decline.

Based on POS theory, we also explore how critical junctures in post-communist trajectories impacted organizational formation. Although there were interest organizations in communist states representing genuine interests, few organizations independent of the communist party and state control existed. As shown in Chapter 2, the 1989-1990 critical juncture did not wipe the field clean. There were new, independent organizations or splinter groups of larger, hitherto official ones that started to form in the 1980s in relatively "liberal" countries such as Hungary or even long before in Slovenia. However, rapid and simultaneous transition from totalitarianism to liberal democracy, from command to market economy, and in many cases to regained or new nationhood is a unique historical experience (Offe, 1994) likely to stimulate organizational population growth:

Hypothesis 2: The period of immediate transition (and statehood in Slovenia and the Czech Republic) positively affects interest organization formation.

EU accession in 2004 constitutes another critical milestone. According to Grabbe (2001), accession led to processes of diffusion, learning and adaptation to European models for interest representation, which potentially may have 
created new POS for CEE organizations. Various authors (e.g. Carmin, 2010; Hanegraaff, van der Ploeg \& Berkhout, 2020) have shown that membership in EU umbrella organizations and transnational networks may positively affect the material and non-material resources of interest groups. Hence, we hypothesize that

Hypothesis 3: EU accession and the run-up to it positively affect interest organization formation.

According to POS theory, legislative activity may also stimulate interest group formation (Meyer \& Imig, 1993; Meyer \& Minkoff, 2004; Nownes, 2004). It not only sends signals to individuals about the importance of an issue, thereby providing them incentives to form organizations, but also may affect the core interests of existing organizations and their constituencies. Reform activity also may generate higher levels of interest intermediation and/or protest. ${ }^{1}$

Hypothesis 4: We expect major reforms and reform attempts to positively affect interest group formation in CEE.

Following POS theory, we additionally provide some preliminary insights on the impact of neo-authoritarian-style governments on organizational ecologies. The trend towards "democratic backsliding" (Bermeo, 2016) and/or national conservatism most notably in Hungary, but arguably also in Poland (Sata \& Karolewski, 2020) with accompanying widespread civic opposition may jumpstart counter-movements. This may boost organizational populations. However, as Greskovits (2020) emphasizes, the illiberal Fidesz party reinvented itself by heavily investing in grassroots, civil society networks after their surprise electoral defeat in 2002. This civic activism of educated middle-class supporters has transformed Hungarian civil society and served as an important factor not only in Viktor Orbán's second, landslide victory in 2010, but contributes to the remarkable political resilience of his regime. Indeed, Orbán's subsequent governments systematically realigned state funds supporting civil society and cultural institutions towards openly right-wing, nationalist and loyal religious organizations (Hungarian Network of Academics, 2020). Ekiert has referred to a similar phenomenon in Poland, namely the emergence of a "dark side of civil society", i.e. new organized interests with illiberal and nationalist objectives (Ekiert, 2019). ${ }^{2}$

Therefore, we assume that:

Hypothesis 5a: "Democratic backsliding" will jump-start civic countermobilization in the form of new organizational foundations.

Hypothesis 5b: Illiberal governments will cultivate alternative "ecosystems" of supporter organizations, leading to an increase in organizational foundations. 
Yet national-conservative governments also may be keen on centralization and authoritarian-style governance, thus cracking down on hostile civil organizations and reducing their means for influence.

Hypothesis 6: "Democratic backsliding" has a negative impact on organizational foundations.

\section{Case selection and methodology}

As outlined in Chapters 1 and 2, we focus on organizations operating in energy, higher education and healthcare in the Czech Republic, Hungary, Poland and Slovenia between 1990 and 2018. While transformation and Europeanization processes are more or less restricted to a particular timeframe, grasping the impact of policy reforms on organizational populations (H4) poses some - arguably unsurmountable - challenges. For example, major reforms were often a direct result of the 1989/1990 transformation process itself (H1), making it difficult to disentangle their effects. EU accession poses the same challenge, as national reforms were often direct reactions to Europeanization processes (H3). Moreover, we may observe long-term reform attempts (e.g. in Czech HE; see Vlk, Dobbins \& Riedel in this volume), which never materialized as intended, but perhaps triggered new organizational formations.

Nevertheless, in line with POS theory, we do our best to differentiate between general structural changes such as the breakdown of communism (H2) or EU accession (H3), and issue-specific changes, that is, major reforms or reform attempts (H4). We opted for a pragmatic approach to pinpointing major reform (attempts) by first drawing on Peter Hall's "three orders of policy change" (1993). "First-order" policy changes aim to readjust existing policy instruments (e.g. university tuition increase, expansion of medical coverage). "Second-order" changes generally introduce new policy instruments (e.g. tuition fees, private health insurance, carbon taxes), while "third-order" changes usually entail a full-scale paradigmatic shift in policy goals (e.g. large-scale privatization of a state-run healthcare or HE system; energy market liberalization). For example, in HE systems, the reinstatement of academic autonomy in 1989/1990 was a third-order change. Poland (and later the Czech Republic) then experienced second-order policy change with the introduction of private universities in the 1990s without dismantling the public system.

Baumgartner (2013) argues, however, that first- or second-order reforms may also trigger significant policy change. For example, a large university tuition increase, major healthcare funding cuts or major increase of carbon taxes (i.e. technically first-order change) may generate large-scale political and organizational mobilization. Therefore, Baumgartner (2013) suggests assessing policy changes based on whether they substantially break up the status quo or not. While this criterion is admittedly softer and more qualitative, we keep it in mind when assessing policy reforms. Thus, for every policy field and country, we identify the four to five most important reforms or reform attempts, many of which 
were triggered by the transformation and Europeanization processes. While we mostly focus on third-order changes, we also include some second- and firstorder reforms, which shook up the political status quo.

Regarding HE, essentially all CEE countries underwent third-order policy change with the quick reinstatement of university autonomy and academic freedom as a cornerstone of democratization. Most CEE countries, including the four analysed here, also experienced massification, i.e. rapidly increasing student numbers. The Bologna Process initiated in 1999 was arguably the largest external reform stimulus in CEE. Driven by Europeanization through transnational "soft governance" and multilateral learning, the process has in some countries resulted in third-order changes such as mass privatization or the fundamental redesign of university governance (Dobbins \& Knill, 2014). Other countries, e.g. the Czech Republic and Poland, underwent more sluggish post-Bologna reforms, resulting in the recalibration of existing institutions or introduction of new structures into existing paradigms (e.g. quality assurance bodies, new forms of student representation) (see Vlk, Dobbins \& Riedel in this volume). Hungary's HE policy pathway has been less consistent. Like the other CEE countries, it first focused on restoring academic self-governance in the early 1990s and then later accountability and market orientation under the Bologna Process (Kováts, Heidrich, \& Chandler, 2017). In 2012-2013, a first-order policy change, namely harsh austerity and cuts in state-funding study places, triggered strong counter-mobilization by the academic community. The recent crackdown on Central European University (CEU) and seizure of the research institute network of the Hungarian Academy of Sciences arguably are third-order policy changes accompanied by mass protests. The new Polish HE Act (2018) also is regarded by observers as a mass overhaul provoking support and opposition from the student and academic community (see Vlk, Dobbins \& Riedel in this volume).

Unlike in HE, CEE countries altogether did not experience major, i.e. thirdorder or large second-order, change, in energy and environmental policy in the early 1990s. Generally, they were regarded as environmental laggards as the political-institutional and economic transformation was prioritized (Skjærseth \& Wettestad, 2007). However, EU integration brought numerous stimuli for changes of all orders. Specifically, the EU's energy acquis prescribes the liberalization of gas and electricity markets (arguably third-order change), as well as major pollution restrictions. Europeanization pressures were reinforced with the European Energy Strategy of 2007, which called for increasing energy supply and security and ensuring the availability of affordable energy, while promoting environmental sustainability. The common energy policy consists of a mixture of both binding measures and softer coordination of energy supply issues and regional markets (Szulecki, Fischer, Gullberg, \& Sartor, 2016). This has prompted all four CEE countries to draft new wide-ranging energy strategies in the past ten years (see Table 3.1).

As laid bare by the coronavirus crisis, healthcare policy generally remains outside the direct orbit of the EU. Nevertheless, European legislation has resulted in numerous, primarily first-order policy changes, including obligations for member states to integrate foreign suppliers into domestic healthcare (Vrangbæk \& 


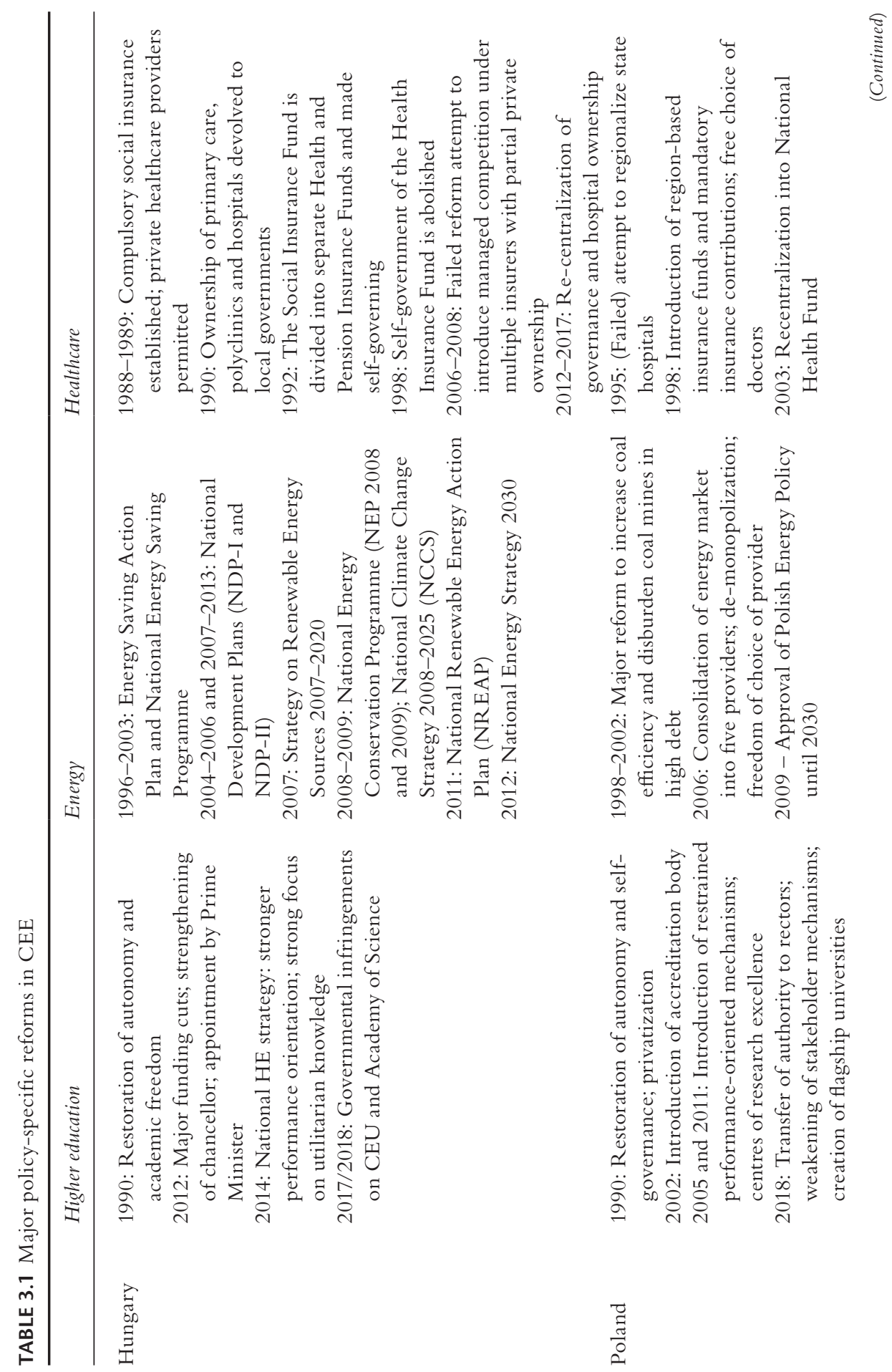


54 Michael Dobbins et al.

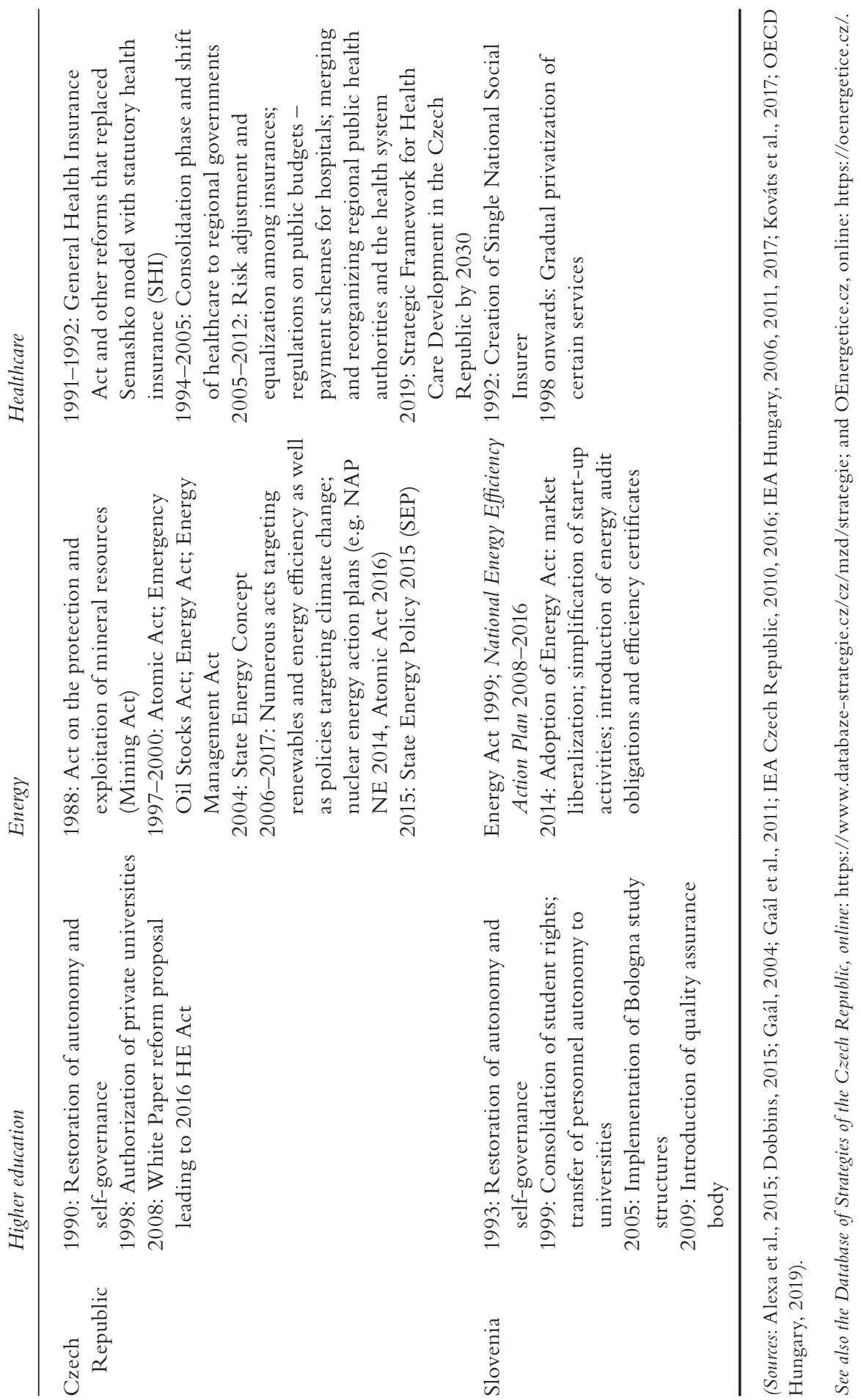


Sindbjerg Martensen, 2008). In specific areas, such as medical trials, data protection and pharmaceuticals, EU regulations also provide common standards and rights, which may exceed those granted by domestic rules. Numerous regulations and directives regarding the movement of medical professionals, patients' rights $^{3}$ and social security also target the sector.

Our countries of analysis experienced large-scale healthcare reforms at different phases of post-communism. The Czech Republic already underwent third-order change early by turning the previously state-run system into a competitive feefor-service system with numerous private insurers (Roberts, 2009). In Poland, by contrast, pre-existing structures initially were preserved. However, the late 1990s heralded several major changes, including the diversification of funding, a new payment concept and the establishment of general practitioner institutions (Grzeskiewicz, 2015; Hellich \& Wierzowiecka, 2017). While funding was initially transferred from the central government to multiple healthcare funds, in 2003 one centralized insurance fund (Narodowy Fundusz Zdrowia) was created.

Hungary introduced a Social Insurance Fund already in 1989 to manage healthcare costs. Between 1988 and 1994, several key reforms introduced decentralization in healthcare provision and self-governance in social insurance. However, from 1994, the direction of reforms was towards re-centralization and cost-cutting (particularly between 1994-1998 and 2005-2008). After 2012, the subsequent Orbán governments completed re-centralization in both healthcare governance (the National Health Insurance Fund Administration was dissolved into the Ministry of Human Capacities) and ownership (hospitals were transferred from municipalities to the central government in 2012) (Gaál, 2004; Gaál, Szigeti, Márton, Gaskins, \& Panteli, 2011; OECD Hungary, 2019). Yet despite extreme underfunding, weak performance by international standards, the migration of medical personnel, Hungarian healthcare has not undergone radical transformational change in the post-communist period. In 1992, Slovenia created a Bismarck-type social insurance system based on a signal national insurer and uniform national legislation. These foundations have essentially remained in place ever since. Nevertheless, gradual privatization occurred over the late 1990s and early 2000s, as various services were supplemented by independent providers by means of contracts with public funds (Albreht \& Klazinga, 2009).

Fully aware of the difficulties in grasping the magnitude of individual reforms, we present a small overview (see Table 3.1) of major reform initiatives and outputs in CEE. We also bear in mind that frustration with the lack of reform despite problem pressure may also stimulate organization population growth.

After compiling lists of organizations and their foundation/dissolution dates (see Chapter 2 for data compilation and limitations), we broke down our organizational populations by type. For HE, we coded each organization as either "student interest", "teacher/employee interest" (typically trade unions), "professional/scientific associations" (e.g. geographical, mathematical society) and "institutional" (e.g. conference of rectors, deans). Regarding professional/scientific associations, we applied strict criteria and only included larger disciplines listed 
in Wikipedia's outline of academic disciplines. ${ }^{4}$ All national-level student associations from all disciplines were included because they are explicitly involved in and affected by HE policy.

For healthcare, we cross-checked whether every specific medical specialization (e.g. immunology, radiology, diabetes) actually exists and coded them by constituency, that is, the professional and/or societal groups they represent: "medical doctors or healthcare professionals", "other employees", "patients", "employers/institutional" and "business".

We coded energy organizations according to sectors, that is, "fossil energy and general energy policy groups", "renewable energy", "nuclear energy" and "green civic organizations/nature protection". Environmental organizations were also included if they express a preference for certain sources of energy (generally renewables, but potentially also nuclear). ${ }^{5}$

\section{Empirical analysis}

We first present some general data on country- and policy-specific population sizes. Table 3.2 shows the frequency of organizations (with an identified foundation date). Altogether, we identified 1,590 organizations across the three policy fields in the four countries, of which a total of $264(16.6 \%)$ were founded before 1990 (see Chapter 2). The data reveal that a country's (human) population size does not necessarily correlate with organizational population sizes, as Czechia's and Hungary's organizational ecology is nearly as large as Poland's with four times as many inhabitants. ${ }^{6}$ Slovenia (population approx. 2 million) exhibits an organization ecology approx. two-thirds the size of Poland's (with 38 million inhabitants). ${ }^{7}$

As for specific policies, healthcare populations are unsurprisingly the largest due to the many specific medical disciplines (e.g. dentistry, immunology, paediatrics) represented by organized interests. In energy, Czechia and Hungary have the largest populations.

As already discussed in Chapter 2, we unfortunately do not have reliable data on "organizational mortality", in particular exact dissolution dates. ${ }^{8}$ Nevertheless, it is worth reporting that we found by far the highest mortality rates in the Czech and Hungarian energy populations, which amount to $50.3 \%$ and $39.3 \%$ of all organizations founded between 1990 and 2018, respectively ${ }^{9}$ (Figure 3.1).

TABLE 3.2 Size and relative size of all interest organizations populations combined (three policy areas)

\begin{tabular}{lcc}
\hline Country & Size & Relative size (\%) \\
\hline Czechia & 409 & 25.72 \\
Hungary & 422 & 26.54 \\
Poland & 461 & 28.99 \\
Slovenia & 298 & 18.74 \\
Total & 1590 & 100.00 \\
\hline
\end{tabular}


TABLE 3.3 Breakdown of all covered organizations by policy area and country

\begin{tabular}{llllrl}
\hline Policy field & \multicolumn{3}{l}{ Country } & \multicolumn{2}{c}{ Total } \\
\cline { 2 - 4 } & Czechia & Hungary & Poland & Slovenia & \\
\hline Energy & 158 & 150 & 135 & 46 & 489 \\
Healthcare & 204 & 188 & 240 & 171 & 803 \\
Higher education & 47 & 84 & 86 & 81 & 298 \\
Total & 409 & 422 & 461 & 298 & 1,590 \\
\hline
\end{tabular}

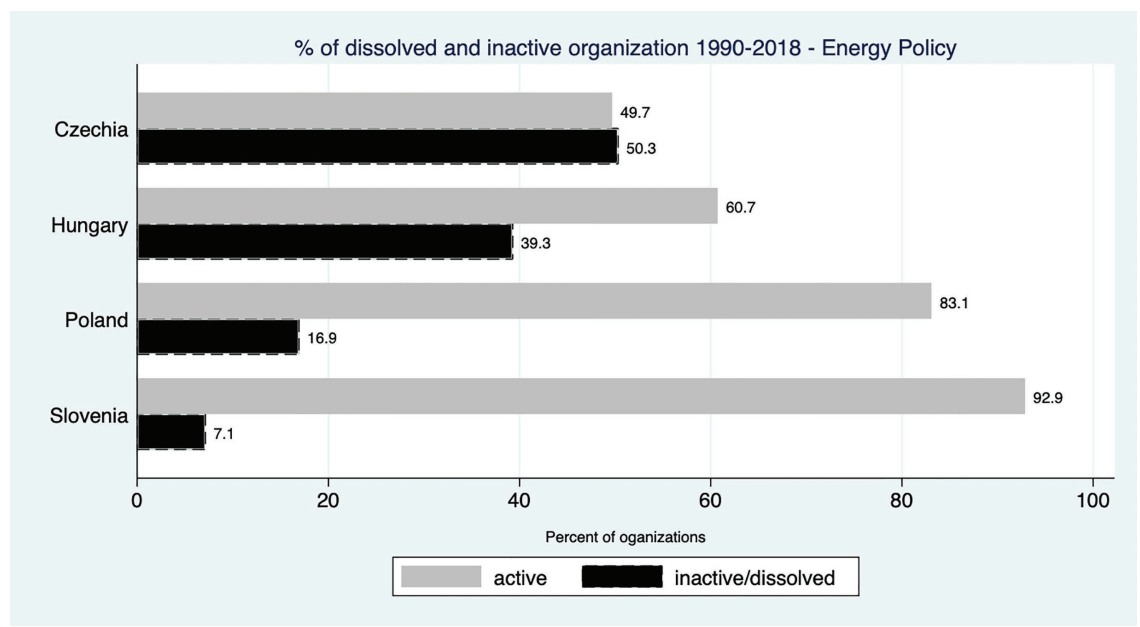

FIGURE 3.1 $1 \%$ of dissolved and inactive organizations - energy policy.

The Hungarian court registry has reliable data on dissolution and inactivity just not on the real dates, as the courts started to legally dissolve inactive organizations as of 2013-2014 - and in the other cases, we systematically checked online whether an organization shows any sign of activity (we double-checked the Hungarian data as well). Thus, we can tentatively conclude that this significantly higher mortality rate among Czech and Hungarian energy policy groups is indicative of the relative differences between the mortality rates of energy policy, $\mathrm{HE}$ and healthcare populations in these two countries. In Czechia, more than $51 \%$ of all general/fossil groups dissolved (38/74), whereas in Hungary only $40 \%$ (33/82). Among renewable groups, the proportions are 54\% in Czechia (23/42) and $38 \%$ in Hungary (19/50). The dissolution rates are also high in the smaller nuclear energy and environmental protection populations. Three of seven and two of eight nuclear groups dissolved in Czechia and Hungary, respectively. 40\% $(14 / 35)$ of the Czech and 30\% (3/10) of the Hungarian environmental protection groups dissolved. 


\subsection{Post-communist organizational foundation rates: energy}

Let us now look at foundation rates in energy policy. For all four countries, populations changed dramatically after 1990. Other than some four or five organizations, Polish energy basically started with a clean slate and then saw an immediate post-communist bump (see Figure 3.3). This was followed, however, by relatively low foundation activity in the 1990s. The run-up to EU accession in 2004 gave a strong boost to energy organization formation, followed by somewhat of a slowdown.

From 2005 to 2007, the national-conservative PiS had a governmental majority. Then, the liberal Platforma Obywatelska (Civic Platform) regained control of the parliament until late 2015. We see renewables and general/fossils groups essentially following the same foundation patterns regardless of governmental coalitions, which can arguably be attributed to heated ideological battles over the direction of Polish energy policy (pro-coal/fossil vs. renewables). The adoption of the 2007 European Energy Strategy and 2009 Energy Strategy until 2030 also coincided with this phase of heavy formation activity, whereas since 2016 we observe a decline in foundation rates, lending some preliminary support to hypothesis 6 (i.e. a slowdown in formations under national-conservative governments).

As shown by Labanino, Dobbins, Czarnecki and Železnik (2020), the founding rates of Polish energy policy organizations do not seem to be density-dependent. Renewable energy organizations proliferated after 2005, but the formation of

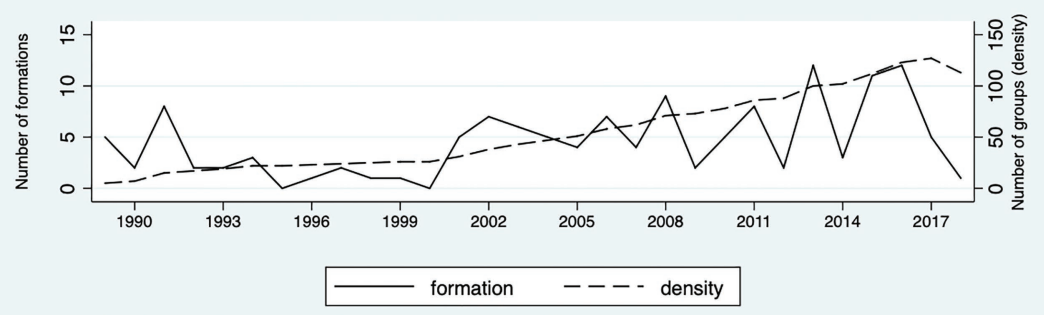

Density and formations of Polish energy policy interest organizations 1989-2018 Source: Polish National Court Registry

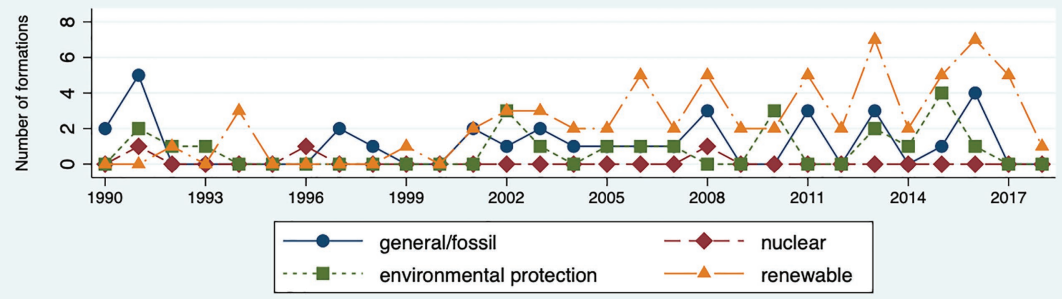

Patterns of formations of Polish energy policy interest organizations 1990-2018 Source: Polish National Court Registry

FIGURE 3.2 Polish energy organizations: formation rates and density, and formation rates by type. 


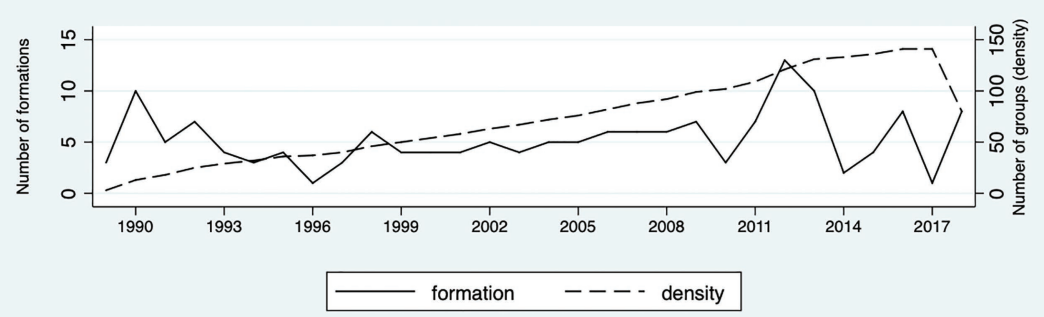

Density and formations of Czech energy policy interest organizations 1989-2018 Source: Czech Statistical Office

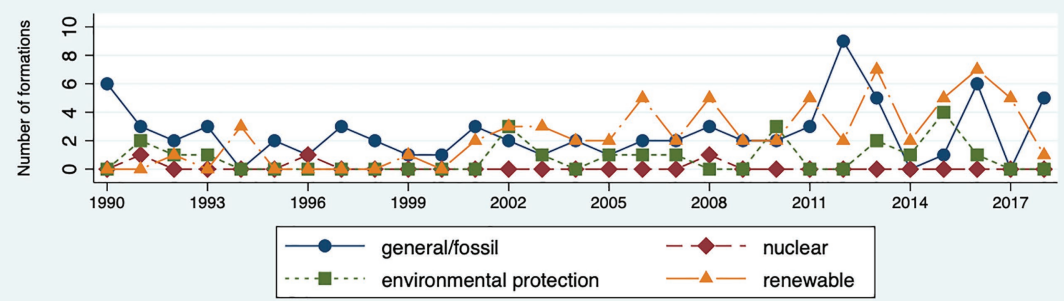

Patterns of formations of Czech energy policy interest organizations 1990-2018 Source: Czech Statistical Office

FIGURE 3.3 Czech energy organizations: formation rates and density, and formation rates by type.

general/fossil as well as environmental protection groups also has several peaks from 2009 on. Perhaps we do not see any saturation yet, because the formation of energy organizations seems to really only "take off" after 2000.

The development of $\mathrm{Czech}^{10}$ energy organizations is roughly similar. After starting with a more or less clean slate in 1989, the new opportunity structure gave a moderate thrust to organizational formation, thus lending moderate support to hypothesis 1 .

In line with hypothesis 2, we observe a steady foundation rate during the EU accession process and then indeed a boom in foundations around the 2010 period, which can be attributed to the 2007 European Energy Strategy. In reaction, the Czech Republic approved its own State Energy Policy in 2015, which outlines the state's energy-related priorities and strategic intentions. Again, here we see a chronological overlap between major reform projects and organizational formation.

The Czech energy formation rates also do not seem to be density-dependent. However, as already discussed, half of all Czech energy organizations are inactive or dissolved (Figure 3.1), and in most cases, the exact date of dissolution (or last year of activity) could not be determined. That is why we see a steep decline in density at the end of the timeframe because we could only be certain that as of 2018-2019 these organizations were inactive (Figure 3.4). Nevertheless, this high mortality rate should make us cautious in making inference about density dependence in this population. 


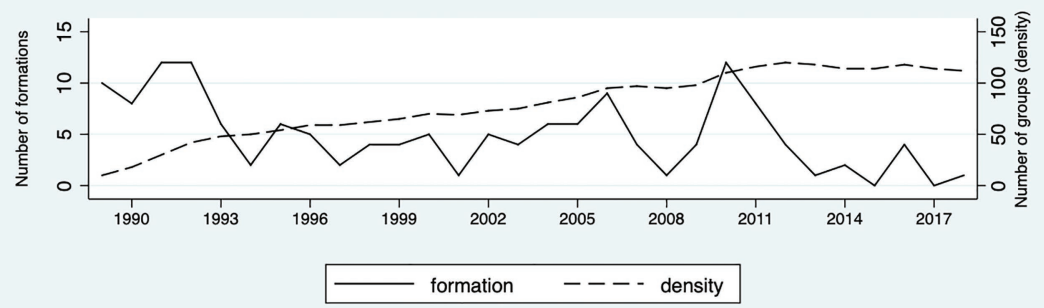

Density and formations of Hungarian energy policy interest organizations 1989-2018 Source: Hungarian Court Registry of Civil Society Organizations

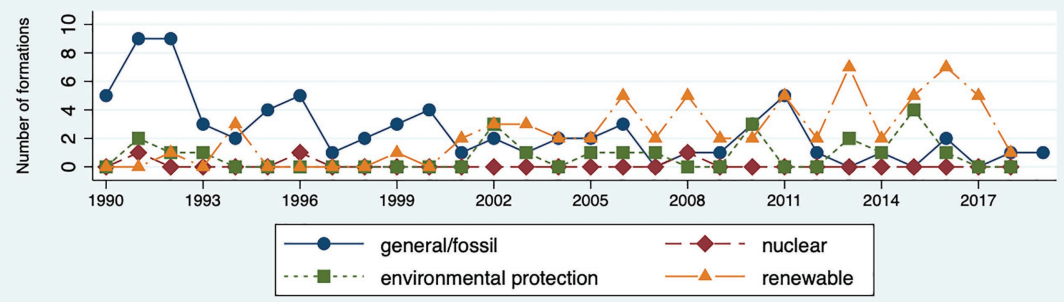

Patterns of formations of Hungarian energy policy interest organizations 1990-2018 Source: Hungarian Court Registry of Civil Society Organizations

FIGURE 3.4 Hungarian energy organizations: formation rates and density, and formation rates by type.

The Hungarian data almost mirror those of the Czech Republic and Poland, with one major difference being the noticeably weak foundation rates since the takeover of the national-conservative Orbán government in 2011, again lending some credence to hypothesis 6 that democratic backsliding may stunt organizational population growth. This observation is further compounded by the fact that Hungary also adopted a major National Energy Strategy in 2012 (Horváthová \& Dobbins, 2019), which seems to have little to no impact on organizational formation.

The Hungarian population also seems more density-dependent than both the Polish and the Czech populations. There are relatively high initial formation rates between 1989 and 1992 along a low initial pre-transition density. As density grows, first there is a 13 -year ebb in formation rates, as predicted by the theory. However, between 2005 and 2009, there are three years with high formation rates with a peak in 2009 (which is on par with the new foundings in the transition years). These foundings are mostly all renewable energy interest groups except for 2011, when five new general/fossil energy groups were founded (Figure 3.5). Then, from 2011 on, energy policy formation rates decline to a historic low though. We would argue that Figure 3.5 shows a legitimacy process at relatively low density and an increasing competition process as density grows, thus supporting the density-dependency hypothesis. Around the middle of the timeframe, we see a temporary uptick in formations as renewable energy groups gained legitimacy from 2001. 


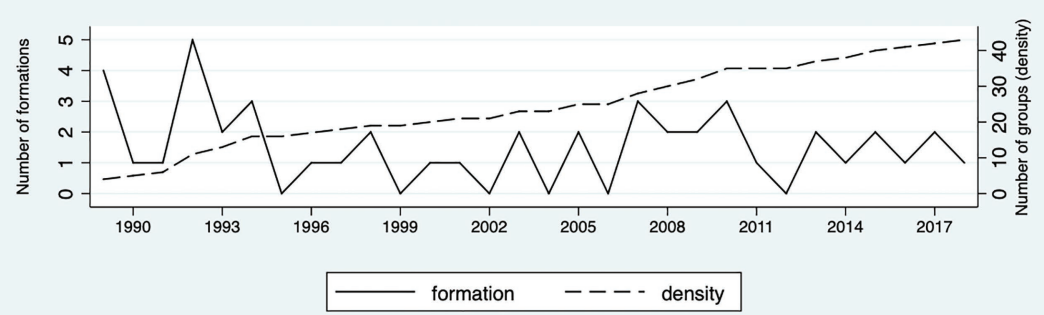

Density and formations of Slovenian energy policy interest organizations 1989-2018

Source: Agency of the Republic of Slovenia for Public Legal Records and Related Services

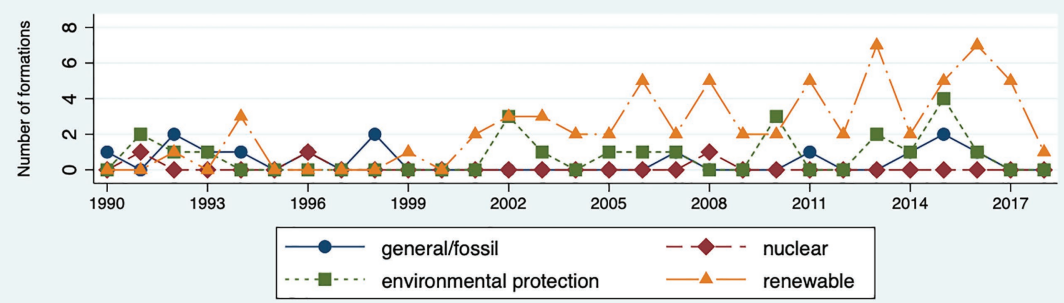

Patterns of formations of Slovenian energy policy interest organizations 1990-2018 Source: Agency of the Republic of Slovenia for Public Legal Records and Related Services

FIGURE 3.5 Slovenian energy organizations: formation rates and density, and formation rates by type.

What first catches the eye regarding Slovenia is the smaller energy policy population in contrast to $\mathrm{HE}$ and healthcare.

Hence, the figures require caution, as two or three foundations per year seem to strongly impact the population. Nevertheless, we see a similar effect of the transition phase (despite the considerable number of foundings in 1989) and EU integration. First, there is a bump, then a slowdown and again a strong increase during the EU accession process. The European Energy Strategy (2007) that inspired the first National Energy Efficiency Action Plan (2008) and second longawaited National Energy Efficiency Action Plan 2014-2020 also coincide with a major push in foundations (Figure 3.6).

The formation rates here are closest to a clear density-dependent process. However, as a post-communist characteristic, we also witness the importance of the immediate transition years, then foundations ebb, and as density grows, formation rates peak again around the half of the timeframe, only to decline steeply again for the third decade.

\subsection{Post-communist organizational foundation rates: higher education}

As discussed in Chapter 2, in the four countries on average one in five HE groups active in 2018 was founded before 1990 (ranging from 33\% in Hungary to 21\% in Czechia). This is a crucial point because organized interests in HE played a key 


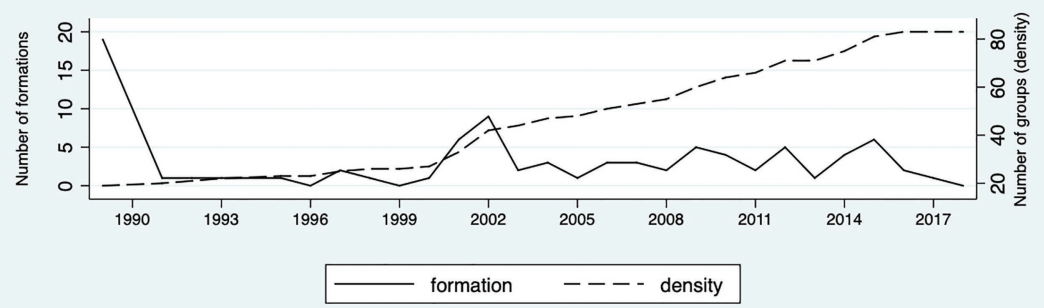

Density and formations of Polish higher education interest organizations 1989-2018 Source: Polish National Court Registry

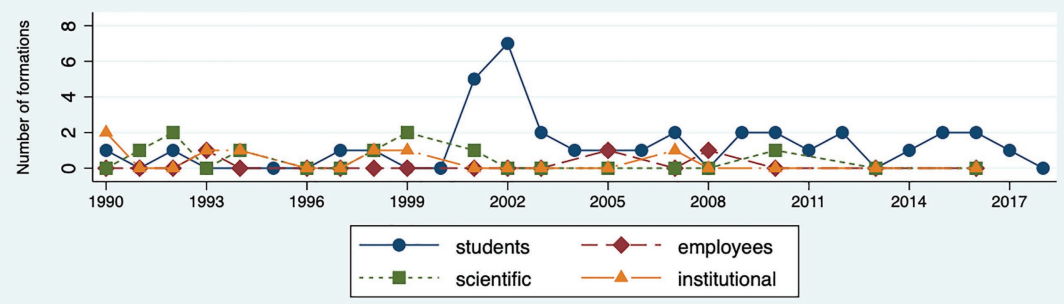

Patterns of formations of Polish higher education interest organizations 1990-2018 Source: Polish National Court Registry

FIGURE 3.6 Polish HE organizations: formation rates and density, and formation rates by type.

role in bringing down communism and institutionalizing democracy. Thus, we can expect a strong mobilization to defend intellectual integrity and university autonomy after communism.

For Poland, where about one-fifth of organizations were founded before or under communism, our graph essentially reflects the immediate massive push to represent university interests in $1989 / 1990$ by means of the establishment of student and academic organizations (e.g. rectors' conferences).

The early authorization of private universities in Poland in the 1990s seems to have not affected the formation rates, whereby Poland - along with Slovenia (see below) - indeed experienced a "Bologna boom" in student organizations. We again see some moderate activity around the 2010 s, likely stimulated by efforts to promote a more market-oriented approach to $\mathrm{HE}$ with greater stakeholder engagement (see Dobbins, 2015). Interestingly, one of the largest public consultation processes in modern Polish history, i.e. the deliberations over the $2018 \mathrm{HE}$ law (see Vlk, Dobbins \& Riedel in this volume), apparently did not stimulate a substantial number of organizational formations. ${ }^{11}$

Just as Labanino, Dobbins, Czarnecki and Železnik (2020) found, density dependence seems to hold, but again is heavily affected by the post-communist context. There is a high initial density and founding rate in 1990 and, consequently, a quickly declining founding rate with minimal or no activity during most of the 1990s. As density slowly grows, there is a peak in formations around 


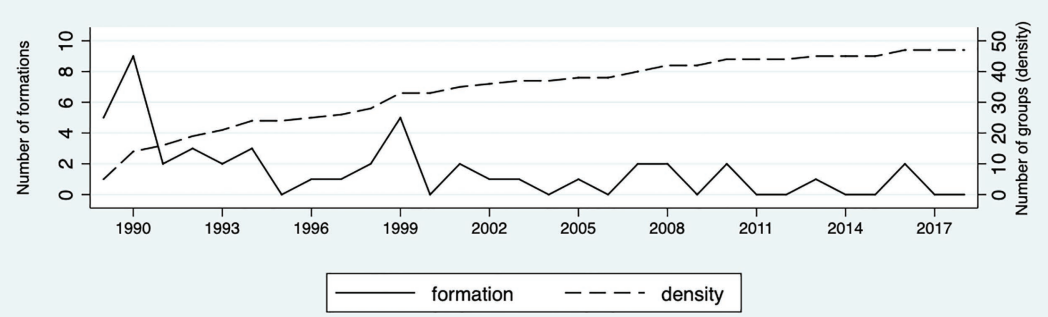

Density and formations of Czech higher education interest organizations 1989-2018 Source: Czech Statistical Office

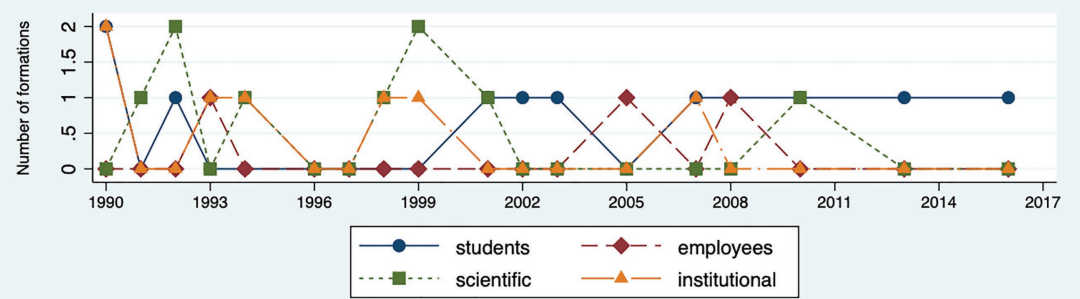

Patterns of formations of Czech higher education interest organizations 1990-2016 Source: Czech Statistical Office

FIGURE 3.7 Czech HE organizations: formation rates and density, and formation rates by type.

the turn of the millennium, followed by lower formation rates, which are nevertheless higher than during the 1990s.

In the Czech Republic, ${ }^{12}$ we also observe large-scale mobilization after the collapse of communism, and then a pre-Bologna "spike" in formations. However, as Bologna did not fundamentally transform Czech $\mathrm{HE}$, we would attribute this growth in organizations to the late authorization of private universities in 1998. Indeed, Figure 3.8 shows a peak in foundations of organizations representing specific (private) institutions between 1999 and 2005. Czech HE has changed little since the fundamentals of university autonomy, self-governance and internal stakeholdership were set in 1990/1991 (see Vlk, Dobbins \& Riedel in this volume). Thus, we also see very little subsequent formation activity. Or, expressed differently, (frustration with) the lack of reform also did not seem to generate organizational births.

Czech HE formation rates do not seem to follow the classic density dependence curve. Nevertheless, high density seems to inhibit the formations of new organizations. Although the pre-transition density is low - as in Czechia in general (see Chapter 2) - no subsequent period matches the importance of the first three years of transition. As already mentioned, mostly due to HE business groups, there are two to three "busier" years around 2000 but then the formations return to one, two or zero formations a year. That is, we did not witness a steady increase and decline as the density dependence theory would assume. 


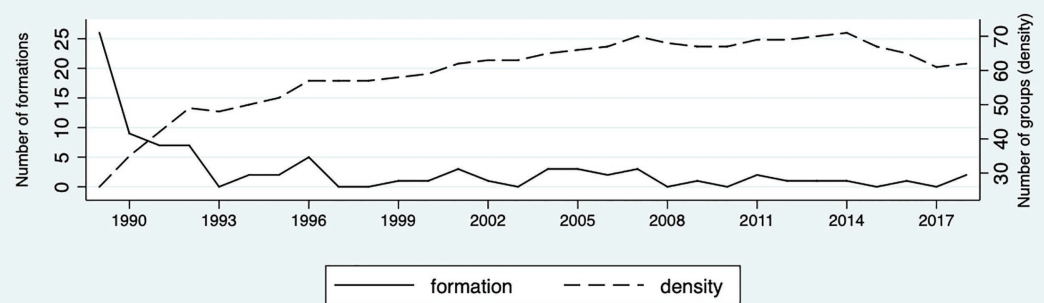

Density and formations of Hungarian higher education interest organizations 1989-2018 Source: Hungarian Court Registry of Civil Society Organizations

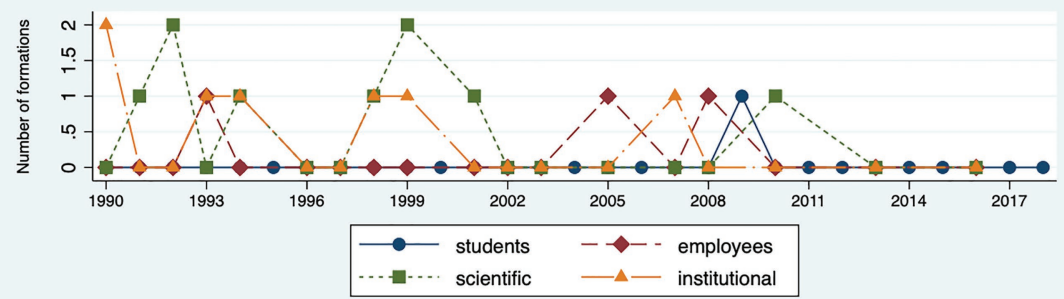

Patterns of formations of Hungarian higher education interest organizations 1990-2018 Source: Hungarian Court Registry of Civil Society Organizations

FIGURE 3.8 Hungarian HE organizations: formation rates and density, and formation rates by type.

We can nevertheless conclude that the first ten post-communist years are the busiest with relatively high formation rates at the end of the decade: more than half of all organizations were founded by 1999.

Hungary is the country with the second highest number of academic organizations - again with 1990 being a landmark year without any notable activity afterwards. Unlike the other countries, we observe - at best - a very weak "Bologna boom" in the late 1990s and early 2000s. What is also striking is that mobilization among academics against intrusions by the Orbán government on internal university workings (e.g. law requiring Hungarian students in state-funded places to remain in Hungary; decreases in university funding; 2012-2013) did not generate new organizational formations. ${ }^{13}$ The same holds with the measures taken against CEU and the Academy of Sciences. In fact, we see almost no new student organization formations in the post-communist phase. In line with our parallel finding for Hungarian energy, this seems to - at least preliminarily - confirm hypothesis 6 , which hints at suppression of organizational foundations by national-conservative governments (Figure 3.8).

The reason could also be, however, that just as the Czech formation process, the Hungarian national-level HE interest group population reached saturation very early. Hungary starts with a very high pre-transition density of 26 , out of which 14 were founded during 1988-1989 (and only three in the entire period between the communist takeover in 1948 and 1987). To put this into perspective, these 


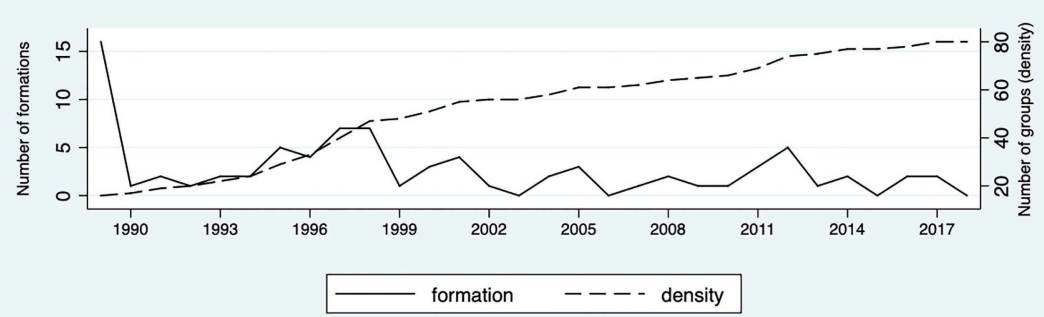

Density and formations of Slovenian higher education interest organizations 1989-2018 Source: Agency of the Republic of Slovenia for Public Legal Records and Related Services

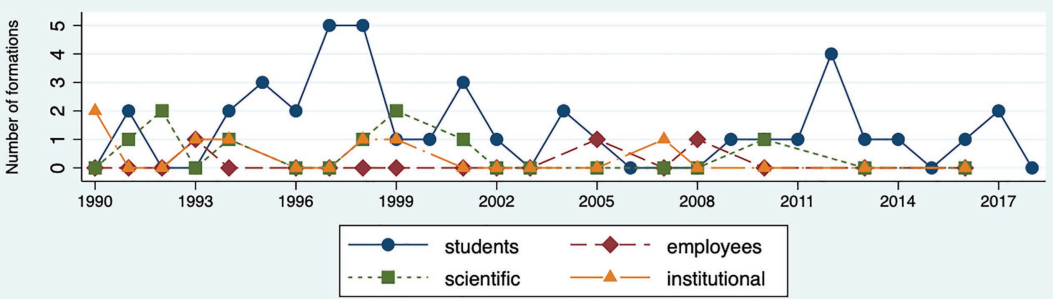

Patterns of formations of Slovenian higher education interest organizations 1990-2018 Source: Agency of the Republic of Slovenia for Public Legal Records and Related Services

FIGURE 3.9 Slovenian higher education organizations: formation rates and density, and formation rates by type.

26 interest groups correspond to $41 \%$ of the HE interest group density in 2018 of 62 organizations (although only 33\% of these 2018 active organizations were founded before 1990). After 1990, formation rates immediately decline steeply to none in 1993, and apart from 1996, it never reaches five organizations a year again. That is, we cannot observe a slow increase with a legitimacy process and a gradual decline with a competition process, but rather that high density affects the formation rate profoundly by keeping it low. In Hungary, density reached 62 in 2001, peaked at 71 in 2014, then declined again to 62 in 2018. Since we had data on dissolutions for Hungary (even if exact dates were sometimes missing), we could also observe that at high density mortality increased (as of 2004).

Slovenia is an outlier regarding the sheer number of organizations, considering the significantly smaller size of this sector (four public universities). We would attribute this to the country's strong tradition of student democracy (Novak \& Fink-Hafner 2019). Student groups have historically represented the multitude of political divisions and social movements in Slovenian society spanning from Catholicism, nationalism, communism, pan-Yugoslavianism, anarcholiberalism, to market socialism and beyond (Plut-Pregelj \& Rogel, 2007). Hence, we find (often long-standing) professional organizations for nearly every academic discipline and sub-discipline (not counted here), as well as a strikingly large number of student organizations. As for formation rates, Slovenia is in line with the other three countries, having experienced a boom in 1989 and then a 
drop, only again to experience a "Bologna boom" before the field levelled out in the 2000s (Figure 3.9).

The HE formation rates (like in the Czech Republic) are closer to a "textbook case" of density dependence than the Polish and the Hungarian cases. Despite relatively high initial density, the foundation rate increases gradually during the late 1990s, and the saturation seems to decrease foundings as density reaches around 60\% of the density in 2018 (around 2000). However, there are a few more active years later as well (2011 and 2012).

\subsection{Post-communist organizational foundation rates: healthcare}

Unlike energy and similarly to $\mathrm{HE}$, between $10 \%$ and $30 \%$ of organizations active in 2018 were founded before 1990. While the lion's share of these preexisting organizations emerged under communism (in Slovenia all of them), between $25 \%$ and $40 \%$ were founded before communist takeovers and hence survived communism and its collapse. This pertains, in particular, to numerous organizations representing individual medical specializations (see Chapter 2).

In line with hypothesis 1 , the immediate transformation period in Poland heralded a major boom in formations, which immediately slowed down from 1990 to 1998. This trend also lends support to hypothesis 4 (reform activity). While the pre-existing fundaments of the Polish healthcare system were essentially left in place in the early 1990s, thus negatively affecting the formation rate, the first major post-communist reform passed in 1997 and implemented in 1999 (see Table 3.1) boosted the formation rate (Hellich \& Wierzowiecka, 2017). When the government replaced multiple health funds with one, centralized National Health Fund in 2003 with regional branches, we again see a "mini-boom" in foundations, while patients' organizations, in particular, have proliferated in this period.

Despite the high pre-transition density, Polish healthcare organizations seem to follow the classic density dependence curve (Figure 3.10). Their number more than doubled in the first ten years after 1990. There is a peak in foundations at a relatively high level of density (60\% of the 2018 density in 2002), followed by a decline in formations. Most new organizations are organizations of medical professionals, which are driven by the increasing specialization in healthcare and medicine. However, even this seems to be density-dependent. From 2002, an increase in patients' organization formations also occurs for several years.

Czech(oslovakia) also experienced a very strong spike in foundations in the 1989-1992 phase. After the 1993 split-up, many previously Czechoslovak organizations became exclusively Czech organizations, which we counted as preexisting organizations. Altogether, our data reveal that there is no major increase in foundations in 1993, which supports hypothesis 2 that the immediate transition period (but not statehood in the Czech case) was the main catalyst behind organizational formation.

We also see a drastic spike in formations coinciding with the transformation and de-monopolization of the previous Soviet-style system into a more privatized 


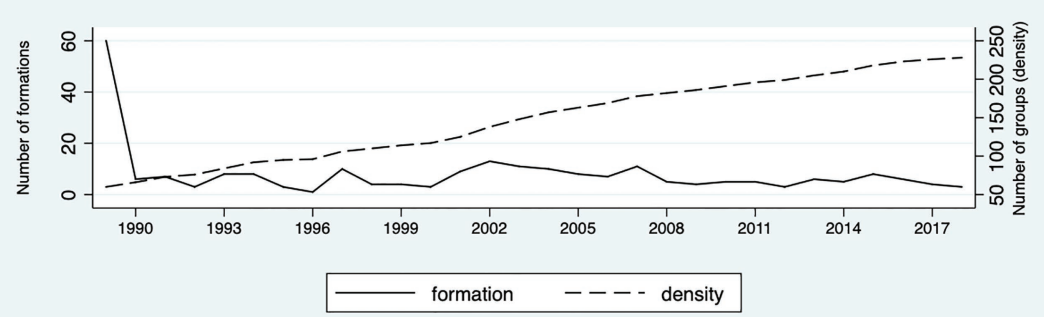

Density and formations of Polish healthcare interest organizations 1989-2018 Source: Polish National Court Registry

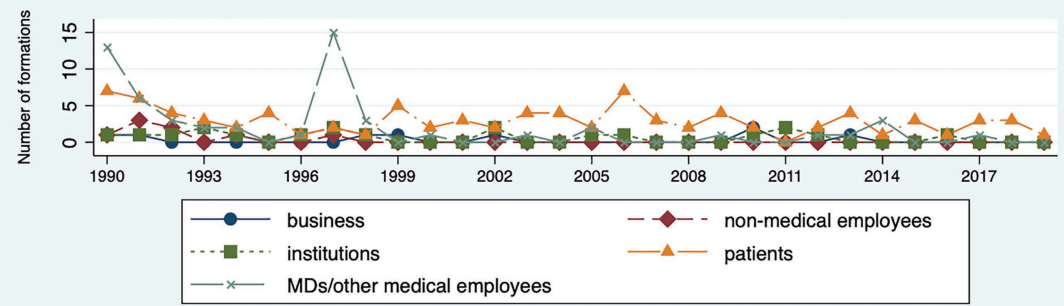

Patterns of formations of Polish healthcare interest organizations 1990-2018 Source: Polish National Court Registry

FIGURE 3.10 Polish healthcare organizations: formation rates and density, and formation rates by type.

system in the mid-1990s (Kinkorová \& Topolčan, 2012; see Horváthová et al. in this volume). Considering that healthcare remains more or less outside the orbit of the European integration process, we would also attribute the strong organization population growth around 2006 to the domestic reform, which shifted hospital ownership to regional management. Thus, along with the immediate transformation process, major reform activity (hypothesis 3) appears to be more decisive for organizational formations than other factors (EU accession, Czech statehood).

As for density dependence, the Czech formation rates, due to the generally low pre-transition density, are closer to the classic density-dependent process than the Polish or Hungarian rates (see below). However, as already noted, the immediate transition years have the highest formation rates. Nevertheless, after a decline but still at a high level - formation rates then increase again significantly in 1997, only to gradually decline again for the remainder of the timeframe (from 1998, see Figure 3.11). It is also telling that although domestic reform activity affected foundation rates at relatively high density (in 2006), it had a much smaller effect than at relatively low density (in 1997).

Hungary entered the 1990 s with a relatively high pre-existing organizational population, and like the Czech Republic and Poland, it experienced a swift increase in 1989 and then a dramatic drop.

In contrast to the other countries, reforms do not seem to have significantly driven organizational foundations in Hungary, other than a few smaller waves 


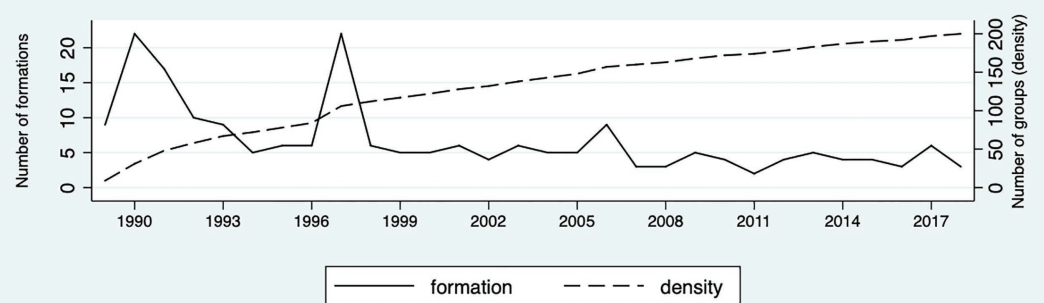

Density and formations of Czech healthcare interest organizations 1989-2018 Source: Czech Statistical Office

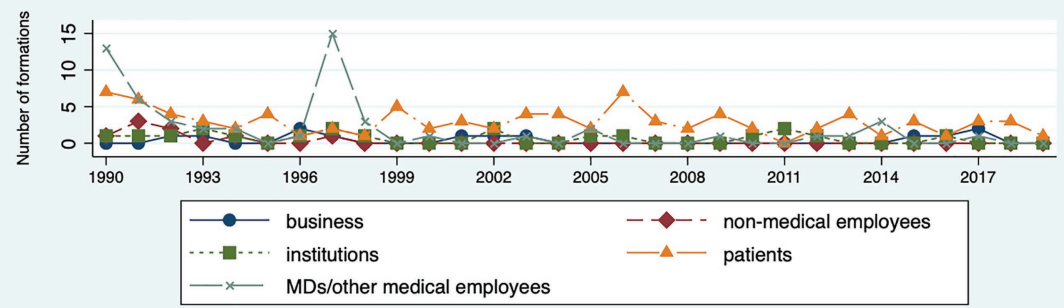

Patterns of formations of Czech healthcare interest organizations 1990-2018 Source: Czech Statistical Office

FIGURE 3.11 Czech healthcare organizations: formation rates and density, and formation rates by type.

of foundations during the 1990s, and the mid-2000s and early 2010s. However, organizational formation rates were exceptionally high during 1988-1989 (15 foundings) when the reform communist government introduced a series of systemic reforms. ${ }^{14}$ Formation rates also remained high between 1990 and 1993 (32 formations) when the first democratic government continued the reforms: it decentralized the ownership of hospitals to local governments, and separated the Social Insurance Fund into a Health Insurance Fund and a Pension Insurance Fund and made them self-governing (Gaál, 2004, pp. 102-104). From 1994 on, Hungarian healthcare reforms moved towards cost containment and gradual re-centralization. Between 2006 and 2008, a failed attempt at partial health insurance privatization took place (Gaál, 2004; Gaál et al., 2011; see also Table 3.1). Thus, the data tend to support hypothesis 1 and - to a somewhat lesser extent than Poland and the Czech Republic - hypothesis 3 (Europeanization). Also noticeable is the marked drop in formations under Orbán (2011 to present). The second Orbán government transferred hospital ownership from municipalities to the central government in 2012. This made it much easier to effectively silence hospital directors and doctors, as their employer is directly the government (OECD Hungary, 2019) and did not stimulate any noteworthy foundation activity.

In Hungary, no other period can compete with the first two years (19901991) in formation rates with a very high pre-transition density of 57 (of which 15 groups were formed during 1988-1989 as mentioned above). Although the 


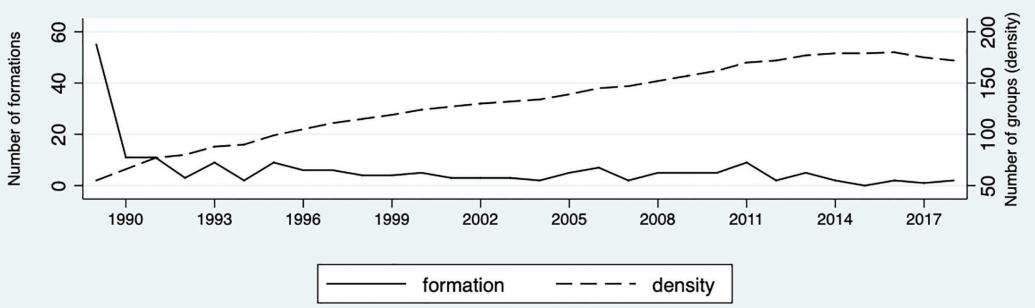

Density and formations of Hungarian healthcare interest organizations 1989-2018 Source: Hungarian Court Registry of Civil Society Organizations

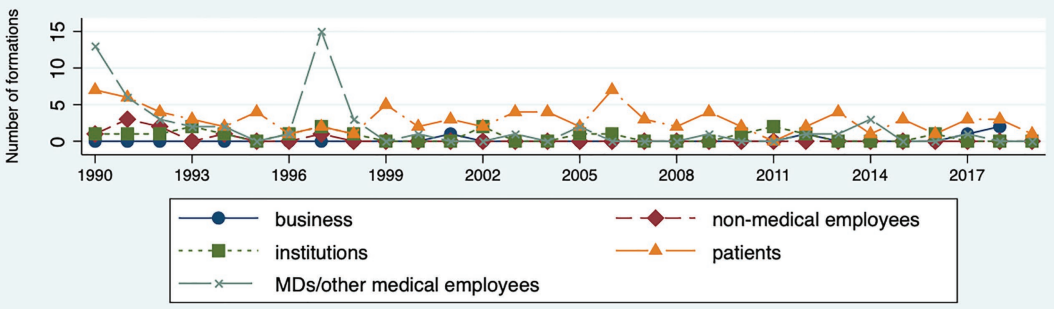

Patterns of formations of Hungarian healthcare interest organizations 1990-2018 Source: Hungarian Court Registry of Civil Society Organizations

FIGURE 3.12 Hungarian healthcare organizations: formation rates and density, and formation rates by type.

formation rates then are similar to the Polish and Czech ones, with some upticks during the 1990s, the interest group density seems to have reached saturation earlier, perhaps due to the earlier start of the transition phase (including 1988 and 1989) (Figure 3.12). Already in 1994, there were 90 national-level healthcare interest groups. Hence, it took four years after transition for the organizational density to reach $50 \%$ of the peak density of 180 groups in 2018. We can therefore conclude that the Hungarian healthcare interest group population density reached saturation very early on. Just as the theory predicts (Hannan \& Carroll, 1992), high organizational density meant increased competition for scarce resources (whether financial, network or organizational), which kept formation rates low. This is exacerbated by the fact that Hungarian healthcare organizations are also remarkably stable with only $9.6 \%$ of them having been dissolved or inactive as of 2018 compared with a $38 \%$ and $26.2 \%$ dissolution rate among energy policy and HE groups, respectively.

While around $20 \%$ of Slovenian healthcare organizations were founded during the socialist period, the immediate transformation again drastically increased the population. Remarkably however, the switch to Bismarck-type social insurance only resulted in a handful of new foundations. These foundations have essentially remained in place ever since, with Slovenia exhibiting a lower level of reform activity. Nevertheless, moderate privatization has gradually occurred over the late 1990s and early 2000s. Our graphs show that this gave an 


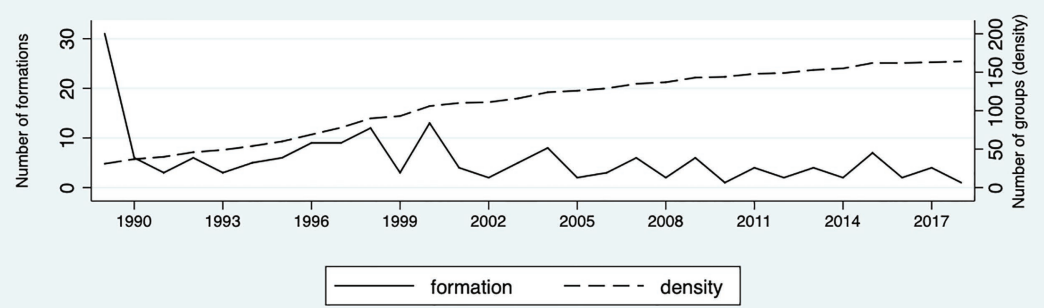

Density and formations of Slovenian healthcare interest organizations 1989-2018 Source: Agency of the Republic of Slovenia for Public Legal Records and Related Services

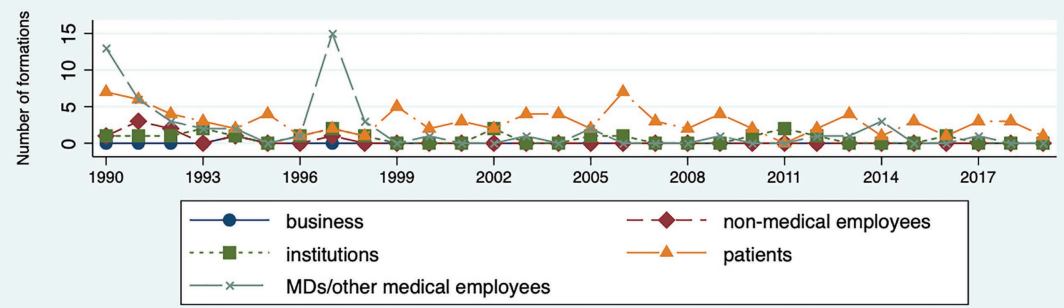

Patterns of formations of Slovenian healthcare interest organizations 1990-2018 Source: Agency of the Republic of Slovenia for Public Legal Records and Related Services

FIGURE 3.13 Slovenian healthcare organizations: formation rates and density, and formation rates by type.

impetus to organizational formations, in particular those representing the medical profession.

These formation rates are similar to the Czech and Polish ones. As noted above, Slovenia had a relatively high density in 1990, but nowhere near the Hungarian levels. Consequently, there was a more gradual saturation around 2000 , followed by a slow decline in formation rates just as in the Czech and Polish cases (Figure 3.13). Bearing in mind that the Slovenian records only contain active organizations, we can tentatively conclude that the formation rates follow a density-dependent process.

\section{Discussion}

In this chapter, we explored the formation of interest organizations in four post-communist countries from a policy-specific angle, while testing several assumptions on the factors driving organizational "births". While our approach does not enable us to identify the exact motivation for establishing an interest group in each individual case, the aggregate data highlight some clear trends. Most notably, the various hypotheses regarding the political opportunity structure were largely confirmed. The transformation and democratization process provided a gigantic stimulus for organizational formation in essentially all 
countries and policy areas, whereby Slovenia and Hungary, in particular, had larger pre-existing populations already. For all countries, we subsequently saw a swift decline in foundations after 1992/1993, followed by a re-acceleration in the late 1990s or early 2000s, fuelled either by national reforms (in healthcare particularly), European integration or a combination of both (e.g. the national implementation of the Bologna Process).

Our data also show that "democratic backsliding" and illiberalism are detrimental or at least not conducive to organizational foundations, in particular in Hungary under Orbán (2010 to present). Except for a spike in foundations of renewable energy organizations in the 2000s, Hungary seems to show the lowest foundational activity in the past 20 years, which we attributed to a combination of the already relatively high density of organizations in the late communist phase (Chapter 2) and the unfavourable climate for interest organizations. For Poland, it is still premature to assess whether the low formation rates since the national-conservative PiS party has ruled (2015 to present) are the result of density dependence effects or a crackdown on civic organizations, but our data do point in the latter direction.

On a positive note from a civil society standpoint, our data also reveal that the past 10-15 years (and 2000-2010 in Hungary) were favourable to the foundation of "diffuse/civic interest groups" (Olson, 1965). We see high birth rates of organizations representing patients, students as well as renewables and green energy groups, all of which typically face structural disadvantages and are attributed to weaker mobilization capacity. Whether such organizations are formally integrated into the decision-making process, how they interact with political parties and whether they actually have clout over policy outcomes remain to be seen in the upcoming chapters.

As mentioned above, we found evidence for density dependence in all 12 national-level populations. The differences between policy fields also seem to be independent from the national contexts. Energy organization populations had the smallest pre-transition density everywhere (see Chapter 2) and hence do not seem to have reached saturation yet. However, we also found the highest mortality rates in the energy populations. HE and healthcare populations reached saturation in every country around 2000 at the latest. How closely the formation rate curve resembles the classic inverted U-shape $\cap$ of increasing formations at growing density and decreasing at high density depends on the size of the pre-transition interest group populations. The bigger the pre-transition density, the earlier an interest group population reaches saturation. That is why Hungarian healthcare and HE populations, which were the biggest of all national populations, show decreasing formation levels already in the late 1990s. Moreover, as shown in Chapter 2, pre-transition organizations have much lower mortality rates than those founded after 1990, which exacerbates this effect. Our data also showed that the effect of both general, structural-level changes (such as the political and economic transition or the EU accession) and major issue-specific changes (policy reforms) is contingent on the level of population density. That is, 


\section{Michael Dobbins et al.}

policy reforms and structural political changes do have a positive effect on formation rates ceteris paribus, but the size of this positive effect depends on population density: at low density, openings in the POS increase interest group formations much more significantly than at high density.

Despite these clear findings regarding our theoretical assumptions, our approach still bears some limitations. In the future, researchers should aim for a clearer operationalization of reform dynamics. This could be done, by means of analysis of media coverage or the frequency of parliamentary hearings or the intensity of legislative activity (Labanino et al., 2020; Nownes, 2004). Other factors potentially affecting interest group growth or decline such as the stability or volatility of the party system or the evolution of lobbying regulations over time lend themselves to empirical analysis. Finally, future research should focus on the long-term impact of national conservatism on organizational populations, as well as attempts by such political movements to cultivate alternative (illiberal) interest group landscapes from a more micro-perspective.

\section{Notes}

1 In line with POS theory, it would also be interesting to look at how (changes in) lobbying regulations or electoral campaign finance legislation affect organizational foundations and/or mortality. Numerous researchers indeed have highlighted differences in the stringency of regulations in our four countries, with Poland and Hungary generally considered to have stricter lobbying regimes with public funding of elections and Slovenia and the Czech Republic more liberal regimes with a larger role of private money in elections (Šimral, 2015; Vargovčíková, 2017). However, lobbying reforms in the region have often been watered down and the ultimate impact of such reforms has been largely viewed as ineffective (Bauer, Pielucha, \& Thiel, 2016).

2 It is an open question whether Czech democracy is also "backsliding" (see Hanley \& Vachudova, 2018).

3 For example, the European patient's cross-border mobility directive.

4 https://en.wikipedia.org/wiki/Outline_of_academic_disciplines; for example, general historical or philosophical associations were included, but not specific organizations such as "The Association of Eastern European Historians" or "The Association of Platonic Philosophy". Moreover, we narrowed down the population to organizations with active university personnel and mentions of HE and science policy or university research on their website.

5 Environmental organizations focusing on biodiversity or animal protection were excluded, except for groups opposing wind energy due to its impact on birds and insects.

6 This may be compensated by more regionally operating organizations in Poland, which is larger and more administratively decentralized. We did not include regionally active organizations.

7 See Novak and Fink-Hafner (2019) or Fink-Hafner (1997) for more data on Slovenian interest groups.

8 We can only be sure to have found all previously existing - at least legally founded but since dissolved organizations in Hungary, as the court registry of the country reliably contains all of them.

9 In Hungary, the proportion of dissolved higher education organizations comes close to the level of energy organization dissolutions but is still lower with 6 percentage points. 
10 This comprises Czechoslovak organizations up to 1993, most of which then split up into Czech and Slovak organizations.

11 However, the court registry does not include the newly emerging protest committees (see Vlk et al. in this volume).

12 Including Czechoslovak organizations up to 1992.

13 See Labanino and Dobbins (2020), who show that academic dissidents have instead opted for non-formalized civic mobilization.

14 Financing was switched from tax-based insurance to compulsory social insurance, the Social Insurance Fund was established, and full private healthcare entrepreneurship was legalized. These reforms were an outcome of a longer process led by the Reform Secretariat at the ministry, which also launched pilot projects. The head of the reform secretary remained in a key position in healthcare policy as a secretary of state along with other technocrats from the pilot projects after 1990 (Gaál, 2004).

\section{References}

Albreht, T., \& Klazinga, N. (2009). Privatisation of health care in Slovenia in the period 1992-2008. Health Policy, 90(2-3), 262-269. https://doi.org/10.1016/ j.healthpol.2008.10.007

Alexa, J., Rečka, L., Votápková, J., van Ginneken, E., Spranger, A., \& Wittenbecher, F. (2015). Czech Republic: Health system review (Vol. 17). Copenhagen: WHO Regional Office for Europe on behalf of the European Observatory on Health Systems and Policies.

Bauer, E., Pielucha, P., \& Thiel, M. (2016). Lobbying regulation framework in Poland. https://www.europarl.europa.eu/RegData/etudes/BRIE/2016/595848/EPRS_ BRI(2016)595848_EN.pdf (Accessed 4 March 2020)

Baumgartner, F. R. (2013). Ideas and policy change. Governance, 26(2), 239-258. https:// doi.org/10.1111/gove.12007

Berkhout, J., Carroll, B. J., Braun, C., Chalmers, A. W., Destrooper, T., Lowery, D., ... Rasmussen, A. (2015). Interest organizations across economic sectors: Explaining interest group density in the European Union. Journal of European Public Policy, 22(4), 462-480. https://doi.org/10.1080/13501763.2015.1008549

Bermeo, N. (2016). On democratic backsliding. Journal of Democracy, 27(1), 5-19. https:// doi.org/10.1353/jod.2016.0012

Carmin, J. (2010). NGO capacity and environmental governance in Central and Eastern Europe. Acta Politica, 45(1), 183-202. https://doi.org/10.1057/ap.2009.21

Dobbins, M. (2015). Exploring the governance of Polish public higher education. European Journal of Higher Education, 5(1), 18-33. https://doi.org/10.1080/21568235.2014. 969289

Dobbins, M., \& Knill, C. (2014). Higher education governance and policy change in Western Europe: International challenges to historical institutions. Basingstoke: Palgrave Macmillan UK.

Ekiert, G. (2019). The dark side of civil society. In J. Zakowski (Ed.), Concilium Civitas Almanach 2019/2020 (pp. 39-59). Warsaw: Concilium Civitas.

An Energy Policy for Europe, SEC. (2007). 12 C.F.R. (2007).

Fink-Hafner, D. (1997). Interest organizations in the policy-making process. In D. Fink Hafner \& J. R. Robbins (Eds.), Making a new nation: The formation of Slovenia (pp. 114-134). Aldershot; Brookfield, WI: Dartmouth.

Gaál, P. (2004). Health care systems in transition: Hungary. Copenhagen: WHO Regional Office. 
Gaál, P., Szigeti, S., Márton, C., Gaskins, M., \& Panteli, D. (2011). Hungary: Health system review. Copenhagen: WHO Regional Office.

Grabbe, H. (2001). How does Europeanization affect CEE governance? Conditionality, diffusion and diversity. Journal of European Public Policy, 8(6), 1013-1031. https://doi. org/10.1080/13501760110098323

Gray, V., \& Lowery, D. (1996). The population ecology of interest representation. Lobbying communities in the American states. Ann Arbor: University of Michigan Press.

Greskovits, B. (2020). Rebuilding the Hungarian right through conquering civil society: The Civic circles movement. East European Politics, 1-20. https://doi.org/10.1080/ 21599165.2020.1718657

Grzeskiewicz, W. (2015). Finance of independent local government public healthcare units after implementation of medical activity act. Problemy Zarzadzania, University of Warsaw, Faculty of Management, 13(53), 129-149. https://ideas.repec.org/a/sgm/ pzwzuw/v13i53y2015p129-149.html (Accessed 4 March 2020).

Hall, P. A. (1993). Policy paradigms, social learning, and the state: The case of economic policymaking in Britain. Comparative Politics, 25(3), 275-296. https://doi. org/10.2307/422246

Hanegraaff, M., van der Ploeg, J., \& Berkhout, J. (2020). Standing in a crowded room: Exploring the relation between interest group system density and access to policymakers. Political Research Quarterly, 73(1), 51-64. https://doi.org/10.1177/1065912919865938

Hanley, S., \& Vachudova, M. A. (2018). Understanding the illiberal turn: Democratic backsliding in the Czech Republic. East European Politics, 34(3), 276-296. https://doi. org $/ 10.1080 / 21599165.2018 .1493457$

Hannan, M. T., \& Carroll, G. R. (1992). Dynamics of organizational populations. Oxford: Oxford University Press.

Hannan, M. T., \& Freeman, J. (1977). The population ecology of organizations. American Journal of Sociology, 82(5), 929-964. https://doi.org/10.1086/226424

Hannan, M. T., \& Freeman, J. (1989). Organizational ecology. Cambridge, MA: Harvard University Press.

Hellich, E., \& Wierzowiecka, A. (2017). Nowy model finansowania szpitali w Polsce szanse i zagrożenia. Studia Ekonomiczne, 333, 77-89. http://cejsh.icm.edu.pl/cejsh/ element/bwmeta1.element.cejsh-67573f31-5c91-437a-82e3-ba327c8dabd8 (Accessed 4 March 2020).

Horváthová, B., \& Dobbins, M. (2019). Organised interests in the energy sector: A comparative study of the influence of interest groups in Czechia and Hungary. Politics and Governance, 7(1), 139-151. http://dx.doi.org/10.17645/pag.v7i1.1784

Hungarian Network of Academics. (2020). Hungary turns its back on Europe. Dismantling culture, education, science and the media in Hungary 2010-2019. Budapest: Hungarian Network of Academics.

IEA Czech Republic. (2010). Energy policies of IEA countries: Czech Republic 2010. https://www.oecd-ilibrary.org/energy/energy-policies-of-iea-countries-czechrepublic-2010_9789264094710-en (Accessed 4 March 2020).

IEA Czech Republic. (2016). Energy policies of IEA countries: Czech Republic 2016 review. https://www.iea.org/reports/energy-policies-of-iea-countries-czech-republic-2016review (Accessed 4 March 2020).

IEA Hungary. (2006). Energy policies of IEA countries: Hungary 2006 review. https://www. iea.org/reports/energy-policies-of-iea-countries-hungary-2006-review (Accessed 29 March 2020). 
IEA Hungary. (2011). Energy policies of IEA countries: Hungary 2011 review. https://www. iea.org/reports/energy-policies-of-iea-countries-hungary-2011-review (Accessed 4 March 2020).

IEA Hungary. (2017). Energy policies of IEA countries: Hungary 2017 review. https://webstore. iea.org/energy-policies-of-iea-countries-hungary-2017-review (Accessed 4 March 2020).

Kinkorová, J., \& Topolčan, O. (2012). Overview of healthcare system in the Czech Republic. EPMA Journal, 3(1), 4. https://doi.org/10.1007/s13167-012-0139-9

Kováts, G., Heidrich, B., \& Chandler, N. (2017). The pendulum strikes back? An analysis of the evolution of Hungarian higher education governance and organisational structures since the 1980s. European Educational Research Journal, 16(5), 568-587. https://doi. org/10.1177/1474904117697716

Labanino, R., \& Dobbins, M. (2020). 'The goal is not necessarily to sit at the table' Resisting autocratic legalism in Hungarian academia. Higher Education Quarterly, advanced online publication. https://dx.doi.org/10.1111/hequ.12290

Labanino, R., Dobbins, M., Czarnecki, S., \& Železnik, A. (2020). Explaining the formation rates of post-communist interest organizations: Density dependence and political opportunity structure. East European Politics and Societies, advanced online publication. https://doi.org/10.1177/0888325420950809

Meyer, D. S., \& Imig, D. R. (1993). Political opportunity and the rise and decline of interest group sectors. The Social Science Journal, 30(3), 253-270. https://doi. org/10.1016/0362-3319(93)90021-M

Meyer, D. S., \& Minkoff, D. C. (2004). Conceptualizing political opportunity. Social Forces, 82(4), 1457-1492. https://doi.org/10.1353/sof.2004.0082

Novak, M., \& Fink-Hafner, D. (2019). Slovenia: Interest group developments in a postsocialist-liberal democracy. Journal of Public Affairs, 19(2), 1-13.

Nownes, A. J. (2004). The population ecology of interest group formation: Mobilizing for gay and lesbian rights in the United States, 1950-98. British Journal of Political Science, 34(1), 49-67. https://doi.org/10.1017/S0007123403000346

OECD Hungary. (2019). OECD economic surveys Hungary 2019. Paris: OECD.

Offe, C. (1994). Das Dilemma der Gleichzeitigkeit. Demokratisierung, Marktwirtschaft und Territorialpolitik in Osteuropa. In C. Offe (Ed.), Der Tunnel am Ende des Lichts. Erkundungen der politischen transformation im Neuen Osten (pp. 57-80). Frankfurt: Campus.

Olson, M. (1965). The logic of collective action; Public goods and the theory of groups. Cambridge, MA: Harvard University Press.

Plut-Pregelj, L., \& Rogel, C. (2007). The A to $Z$ of Slovenia. Plymouth: Scarecrow Press.

Roberts, A. (2009). The politics of healthcare reform in postcommunist Europe: The importance of access. Journal of Public Policy, 29(3), 305-325. https://doi.org/10.1017/ S0143814X09990110

Sata, R., \& Karolewski, I. P. (2020). Caesarean politics in Hungary and Poland. East European Politics, 36(2), 206-225. https://doi.org/10.1080/21599165.2019.1703694

Šimral, V. (2015). The funding and oversight of political parties and electoral campaigns in Central and Eastern Europe. Prague: Frank Bold.

Skjærseth, J. B., \& Wettestad, J. (2007). Is EU enlargement bad for environmental policy? Confronting gloomy expectations with evidence. International Environmental Agreements: Politics, Law and Economics, 7(3), 263-280. https://doi.org/10.1007/ s10784-007-9033-7 


\section{Michael Dobbins et al.}

Szulecki, K., Fischer, S., Gullberg, A. T., \& Sartor, O. (2016). Shaping the 'Energy Union': Between national positions and governance innovation in EU energy and climate policy. Climate Policy, 16(5), 548-567. https://doi.org/10.1080/14693062.2015.1135100

Vargovč́́ková, J. (2017). Inside lobbying regulation in Poland and the Czech Republic: Negotiating public and private actors' roles in governance. Interest Groups \& Advocacy, 6(3), 253-271. https://doi.org/10.1057/s41309-017-0026-9

Vrangbæk, K., \& Sindbjerg Martensen, D. (2008). The Europeanization of health care governance: Implementing the market imperatives of Europe. Public Administration, 86(1), 169-184. https://doi.org/10.1111/j.1467-9299.2007.00702.x 